\title{
等級の異なるスケトウダラ冷涷すり身のかまほこ品質に対する 牛血漿粉末添加の影響
}

\author{
阿部洋一, 安永広作, 北上誠一, 太田隆男
}

(1994 年 10 月 20 日受付)

\author{
Quality of Kamaboko Gels from Walleye Pollack Frozen Surimis of \\ Different Grades with Bovine Plasma Powder \\ Yoichi Abe, ${ }^{* 1}$ Kosaku Yasunaga, ${ }^{* 2}$ Seiichi Kitakami, ${ }^{* 3}$ and Takao Ota ${ }^{* 4}$
}

\begin{abstract}
Six kinds of walleye pollack frozen surimis of different grades were subjected to the preparation of kamaboko gels with and without the addition of $0.5 \%$ bovine plasma powder. The quality of the kamaboko gels thus obtained was evaluated by measuring the gel properties such as the breaking strength, breaking strain, gel strength, and spring constant. It was found that the addition of bovine plasma powder remarkably enhanced the gelling ability of all kinds of frozen surimis, although the apparent increment in gel properties of the kamaboko was larger in the frozen surimi of lower grade than that of higher grade. However, the quality of the kamaboko gel prepared from the frozen surimi of lower grade on addition of plasma was still remained inferior to that from the highest grade without the addition of plasma. These results also supported our previous conclusion that the gelling of frozen surimi with bovine plasma powder proceeded via slightly different way as compared to the case without plasma.
\end{abstract}

キーワード：牛血漿, フラズマ, かまほこ，スケトウダラ，冷涷すり身，ゲル物性

さきに著者らの一人は，スケトウダラ冷凍加塩すり身

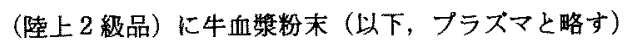
を添加したかをほこを作り，そのゲル物性に対する影響 を調べだ”その結果, 予備加熱温度が $30^{\circ} \mathrm{C}$ 以下では かまほこの破断強度上破断出みを強化するように，また $40^{\circ} \mathrm{C}$ 以上ではそれらの减少を抑制するように作用する こと，さらにその添加量は $0.5 \%$ が適当であることなど を知った。

現在冷凍すり身の流通の主体は無塩すり身であり，ぬ た，等級む SA 級から2 級とさまざまである。本研究で は，等䄲の異なるスケトウダラ冾凍すり身に市販のブラ ズマ標品を添加してかまぼこを製造し，そのゲル物性に 及活す影㽚について比較険討した。

\section{実験方法}

本研究で使用したスケトウダラの冾凍すり身の等級と 性状をTable 1 に記載した。
かまぼこの調製 冷凍すり身を解凍後、小型サイレン トカッター（俳屋製作所）で約 1 分間擂潰した。無 塩すり身の場合は $3 \%$ 食塩を添加，加塩すり身の埸合 は食塩無添加で，さらにこれらに0.5\%フフラズマを添加 して 12 分間擂潰した。すり上がり後の肉糊の温度は約 $9^{\circ} \mathrm{C}$ とした。この肉糊を折径 $48 \mathrm{~mm}$ のポり塩化ビニり デン製チューブに充填し， 25 および $40^{\circ} \mathrm{C}$ の恒温水槽中 て所定時間 ( $0 \sim 5$ 時間) 加熱した（この加熱処理を予 備加熱之呼ぶ) 後, さらに $90^{\circ} \mathrm{C}$ の水槽中で 30 分間加 熱した（これを二段加熱ゲルまたはかまほこゲルと呼 ぶ。なお，ブラズマ無添加のかまぼこを凉照とした。 ここで使用したブラズマは，太陽化学(侏より貶売され ている製品（商品名：フィッシュアップB）で，100\% 牛血漿粉末さされている

また，SA級と2級のすり身中タンパク質淟度を挮古 る際には，SA 級に対し添加物を添加する前のすり身の 水分が一定となるように加水した。

*1 株式会社阿部十良商店 (Abe Jyuro Co., Ltd., Abashiri, Hokkaido 093, Japan).

*2 中央水産研究所 (National Research Institute of Fisheries Science, Fukuura, Kanazawa, Yokohama, Kanagawa 236, Japan).

*3 全国安り身協会技術研究所（National Surimi Manufacturers Association, Abashiri, Hokkaido 093, Japan).

*4 株式会社日本食品開発研究所 (Japan Food Research and Development Institute Co., Ltd., Ichinohasi-miyauti, Higasiyama, Kyoto 605, Japan). 
Table 1. Frozen surimis from walleye pollack used in the study

\begin{tabular}{|c|c|c|c|c|c|c|}
\hline \multicolumn{2}{|c|}{ Grade } & \multirow{3}{*}{$\begin{array}{l}\text { Product } \\
\text { U.S.A. }\end{array}$} & \multirow{2}{*}{$\begin{array}{r}\text { Additives } \\
\text { Sugar: } 9 \%\end{array}$} & \multirow{3}{*}{$\begin{array}{c}\text { Moisture } \\
75.5 \%\end{array}$} & \multirow{3}{*}{$\begin{array}{l}\mathrm{pH} \\
7.24\end{array}$} & \multirow{3}{*}{$\frac{-20^{\circ} \mathrm{C} \text { Period (month) of storage }}{14}$} \\
\hline (A) & SA & & & & & \\
\hline & & & PP: $\quad 0.2 \%$ & & & \\
\hline \multirow[t]{2}{*}{ (B) } & SA & U.S.A. & Sugar: $9 \%$ & $76.2 \%$ & 7.16 & 10 \\
\hline & & & PP: $\quad 0.2 \%$ & & & \\
\hline \multirow[t]{2}{*}{ (C) } & 2nd & JAPAN & Sugar: $5 \%$ & $80.6 \%$ & 7.15 & 2 \\
\hline & & & PP: $\quad 0.2 \%$ & & & \\
\hline \multirow[t]{2}{*}{ (D) } & 2 2nd & JAPAN & Sugar: $5 \%$ & $80.6 \%$ & 7.34 & 0 \\
\hline & & & PP: $\quad 0.2 \%$ & & & \\
\hline \multirow[t]{2}{*}{ (E) } & salted & U.S.A. & Sugar: no record & $73.3 \%$ & 6.70 & 4 \\
\hline & $\mathrm{Fa}$ & & Salt: no record & & & \\
\hline \multirow[t]{2}{*}{ (F) } & salted & JAPAN & Sugar: $10 \%$ & $76.0 \%$ & 6.80 & 2 \\
\hline & 2nd & & Salt: $2.5 \%$ & & & \\
\hline
\end{tabular}

PP: polyphosphate salt.

かまぼこの弾力測定 調製した二段加熱ゲルを流水で 冷却後， $25^{\circ} \mathrm{C}$ の佰温槽中に保管した。品温が $25^{\circ} \mathrm{C}$ にな ったものを，厚さ $25 \mathrm{~mm}$, 直经 $30 \mathrm{~mm}$ の円柱状試験片 とし、レオメーター（不動工業製 NRM2002J）を使用 し，直径 $5 \mathrm{~mm}$ の球形プランジャー（進入速度 $6 \mathrm{~cm} /$ $\mathrm{min})$ で破断強度（g）上破断凹み（mm）を測定した。

ゲル強度およびバネ定数の計算方法 前報卓と同様 に，破断強度と破断凹みの積をゲル強度 $(\mathrm{g} \cdot \mathrm{cm})$ ，破断 強度を破断凹みで割った值を，破断時に扔けるバネ定数 $(\mathrm{g} / \mathrm{cm})$ と表した。

\section{実験結果}

二段加熱ゲル（かまばこゲル）のゲル物性に対するプ ラズマ添加の影響 6 種類の冷凍すり身にブラズマを添

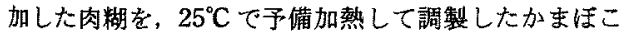
ゲルについて，破断强度および破断山みを測定し，予備 加熱時間との関係を Fig. 1 に示した。

いずれの場合む予備加熱時間の経過とともに破断強度 上破断凹みは增加し，ブラズマを添加した方がより速や 汃，加大きな值に達した。破断強度では，2級品の 一種と，加塩FA級品の場合を除いて，予備加熱 5 時 間媵もなお最大值に達せず増加し続け，この㑯向はブラ ズマを添加したものの方がより著しかった。これに対し て，破断凹々の方はとんどの場合に最大值に達してい た。

一方，ブラズマ添加のゲル物珄への影整はすり身の等 䄲にるり異なり，見か十等䄲の劣るすり身の方が大き く強化された。すなわち，等級の優れた SA 級品や加塩 FA級品に招いては，予備加熱にともない，プラズマ添
加のほうが，無添加よりも常に破断強度で 10〜20\%， 破断凹みで 5 10\% とほぼ一定の割合で高い値であり， 2 級すり身においては，ブラズマ添加によって破断強度 で 40 100\%，破断凹みで 13〜40\%程高い值であっ た。

このように，フラズマの添加によるゲル物性の強化の 程度には，本来そのすり身が保有しているゲル形成能の

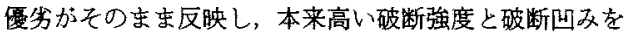
示寸むのではさらに高い值に達するが，それらの低いむ のでは，プラズマによって強化を図っても，な掋い值 に留まった。すなわち，2級，加塩 2 級，および加塩 FA 級のすり身からブラズマを添加して得たかまほこの 物性は，SA級のすり身からプラズマを添加せずに調製 したがほこのゲル物性值になお及ばない。このことは 破断強度と破断凹みのいずれにむ諮められた。

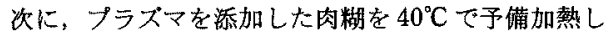
て得たかをほこゲルの破断強度抢よび破断凹及と予備加 熱時間との関保を Fig. 2 に示した。

$25^{\circ} \mathrm{C}$ の場合と異なり，かまぼこゲルの破断強度と破 断凹みは，予備加熱の経過に伴って $25^{\circ} \mathrm{C}$ の場合のよう に一方的な増加をしなかった。ブラズマ無添加の場合に は予備加熱の経過につれてゲル物性の低下が起こった が，ブラズマの添加はこれを抑制した。 SA 級抢よび加 塩FA 級では，予備加熱の初期に一旦僅加に增加した 後，减少する傾向を示しているが，フラズマの添加によ りその減少は抑制され，ほぼ一定値を保った。無添加の すのが最大値に達する条件下で比べれば，ブラズマ添加 による強化の程度は破断強度で 4 19\%，破断凹みで 2〜5\%であった。一方，2級のすり身では，そのゲル 

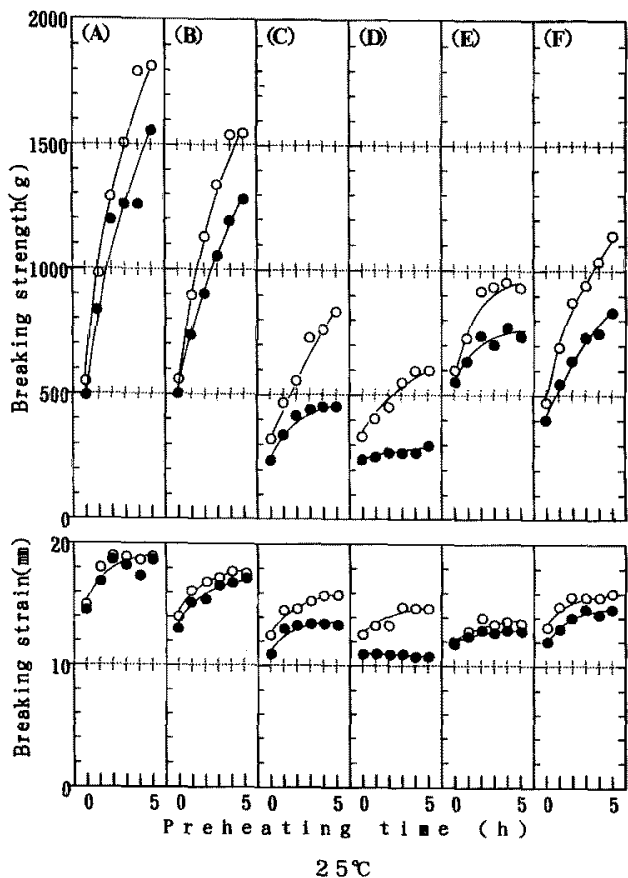

Fig. 1. Changes in the breaking strength and breaking strain of two-step heating gel from walleye pollack frozen surimi of different grades with bovine plasma powder as a function of preheating time at $25^{\circ} \mathrm{C}$.

(A) SA grade; (B) SA grade; (C) 2nd grade; (D) 2nd grade; (E) Salted FA grade; (F) Salted 2nd grade.

Salt-ground meats were prepared from walleye pollack frozen surimi at $9^{\circ} \mathrm{C}$ or bellow with and without $0.5 \%$ bovine plasma powder. The salt-ground meat was stuffed into a polyvinylidene tube $(\phi 30 \mathrm{~mm})$ and preheated at $25^{\circ} \mathrm{C}$ for various times and followed by heating at $90^{\circ} \mathrm{C}$ for 30 minutes. The two-step heating gel thus formed was sliced into $25 \mathrm{~mm}$ thickness and subjected to the measurement of the breaking strength $(\mathrm{g})$ and the breaking strain (mm) with a rheometer (Fudoh Co. Ltd., NRM2002J) by adopting a spherical plunger $(\phi 5 \mathrm{~mm})$.

•, without plasma; $\bigcirc$, with $0.5 \%$ plasma.

物性は，無添加の場合は一方的に減少する㑯向を示すの に対し，ブラズマを添加した方はほほ初めの值を保っ た。この場合のゲル物性の最大値は，予備加熱時間が 0の時であるが，ブラズマ添加による增加の程度は破断 強度で 30\%，破断凹及で $13 \%$ であった。なお，加塩 2 級品では，ゲル物性は，一旦增加した後大きく減少して
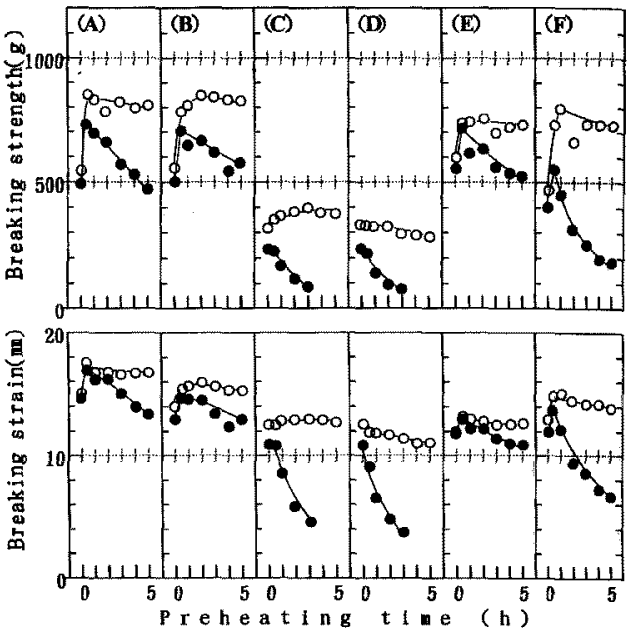

$40^{\circ} \mathrm{C}$

Fig. 2. Changes in the breaking strength and breaking strain of two-step heating gel from frozen surimi of different grades with bovine plasma powder as a function of preheating time at $40^{\circ} \mathrm{C}$.

Salt-ground meats were prepared from walleye pollack frozen surimi with and without $0.5 \%$ bovine plasma powder. Preparation of two-step heating gels was then made as in Fig. 1 , except that the preheating of the salt-ground meat was made at $40^{\circ} \mathrm{C}$.

The breaking strength ( $\mathrm{g}$ ) and the breaking strain (mm) were measured also as in Fig. 1.

(A) $\sim(\mathrm{F}), \bullet$, and $O$; the same as in the legend of Fig. 1.

いるが，プラズマを添加した方はその值を保った。この ブラズマ添加をしたかまほこのゲル物性は，無添加のも のの方が最大值上なる時間で比べる上破断強度で $30 \%$, 破断山及で $7 \%$ 程大きいむのであった。

$40^{\circ} \mathrm{C}$ の予備加熱では，いずれの等級のすり身加らの 場合子，無添加の方のゲル物性は最大值に達した後结低 下する傾向を示すため，プラズマ添加と無添加のゲル物 性の差は予備加熱時間に伴って大きくなり，この差異は 特に 2 級のすり身の方が影著であった。しかし，プ ズマ添加によるゲル物性の強化に法限界があり，添加に より得られたかなぼこのゲル物性は，SA 极のすり身加 らプラズマ無添加で調製したかをほこのそれよりむ例外 なく劣った。加塩 2 級と加塩FA 級の場合は，ブラズ マ添加により破断強度はSA 級（無添加）加らの加汪 こに匹敵したが，破断凹みはなお及持なかった。

また、このような傾向は，品質の異なる2 級のすり 
身，たとえば 2 級拉よび加塩 2 級のようKゲル物性の より高いむのと低いものとの間で比べた場合でも同じで あった。

プラズマを添加して得たかまばこゲルの物性上の特徽 調整されたかま法こゲルの物性上の特致を考察するため に，破断强度および破断凹みから計算したゲル強度およ びバネ定数と予備加熱時間との関保を，Fig. 3 および

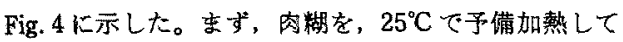
得たかまほこゲルの量合，ゲル強度とバネ定数に対する ブラズマ添加の影慗は，いずれも，破断強度への影響 (Fig. 1) の場合と良く似ており，いずれの等級のすり 身加ら調製したかまほで゙，プラズマ添加による強化 の効果は，はっりと諘められる。しかし，その効果に は限界があり，等級の低いすり身からプラス゚マ添加によ って得たか亦ほこのゲル物性は，等級の高いすり身のゲ

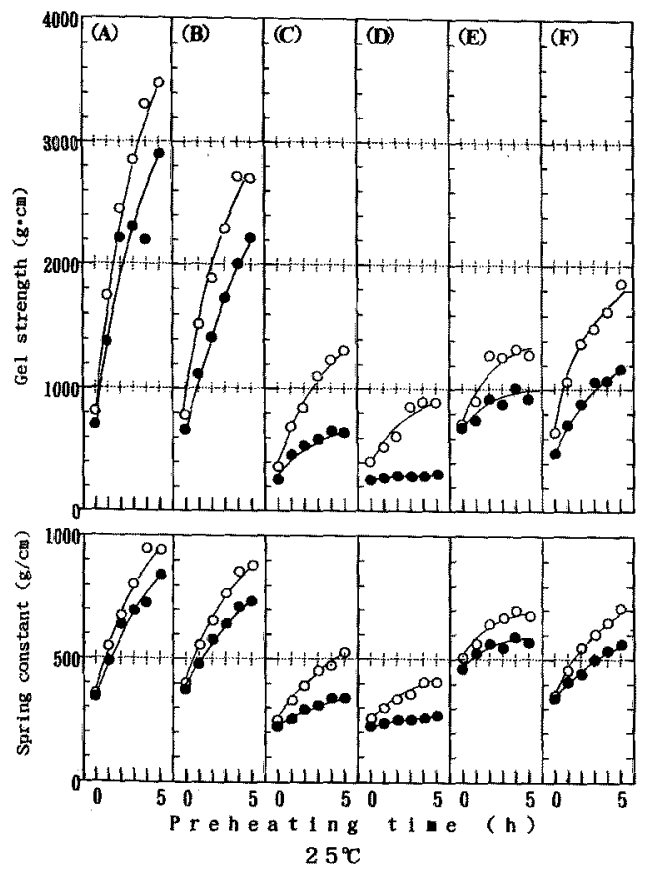

Fig. 3. Changes in gel strength and spring constant of two-step heating gel with bovine plasma powder as a function of preheating time at $25^{\circ} \mathrm{C}$.

From the data shown in Fig. 1, the gel strength was calculated by the breaking strength $\times$ breaking strain and the spring constant was calculated by the breaking strength/ breaking strain.

(A) $\sim(F), \bullet$, and $O$; the same as in the legend of Fig. 1.

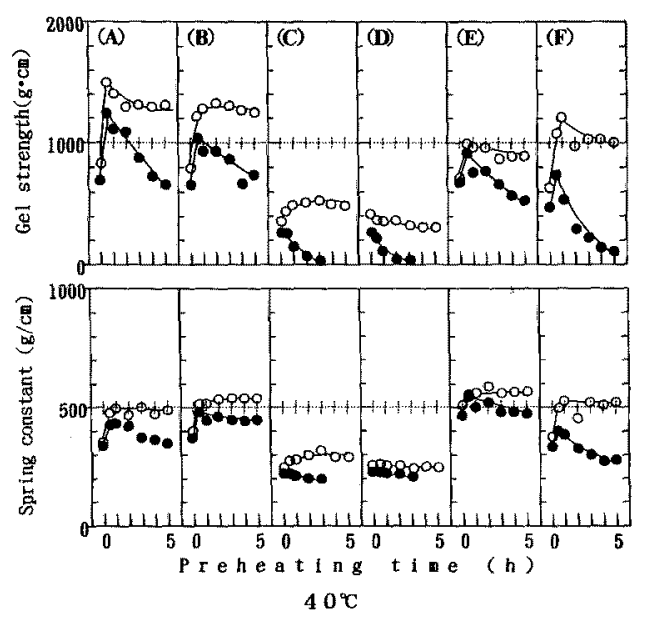

Fig. 4. Changes in gel strength and spring constant of two-step heating gel with bovine plasma powder as a function of preheating time at $40^{\circ} \mathrm{C}$.

From the data shown in Fig. 2, the gel strength and the spring constant were calculated in the same way described in the legend of Fig. 3.

(A) $\sim(F), \bullet$, and $O$; the same as in the legend of Fig. 1.

ル物性を追い越すものではなかった。

次に，40ㄷ C゙予備加熱して得た加まにゲルの場合， ゲル強度怙よびバネ定数に娰するブラズマ添加の影響 は，いずれむ，破断強度および破断田文に対する影響 (Fig. 2) 上良く似ており，ブラズマによる物性強化は ゲル強度とバネ定数の減少を抑制し，一定値を保った。 しかし，この場合もその效果には限界があり，等級の低 いすり身のかま活こゲルは高いすり身のむのを追い越す ほどではなかった。

すり身の等級によるプラズマ添加の影翼 2 級と SA 級のすり身を比べると，原料およびその製造時における さまざな条件の違いもあるが，特にすり身の水分と添 加物量に違いがあり，これは，すり身中に含まれるタン パク質漂度の違いに反映する。つまり，水分量の高い 2 級すり身では，プラズマ添加によるMf タンパク質濃 度の低下むより大きくなる。そこで，SA 級のすり身に 加水をして2 級すり身並の水分量に調整し，タンパク 量が同じかをほこを調製し，それらの物性を比較した。 すなわち，破断強度と破断凹みを Fig. 5 に，なたゲル 強度とバネ定数をFig. 6 に示す。

これらによると，加水した SA 娐すり身 (以下， SA

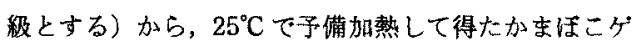




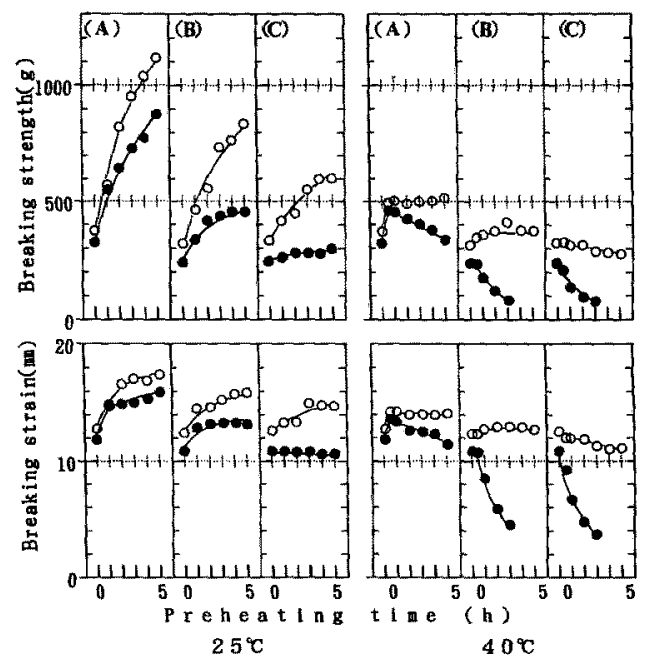

Fig. 5. Comparison of changes in the breaking strength and breaking strain between two-step heating gels from SA' grade (SA grade adjusting moisture content) and 2 nd grade frozen surimis with and without bovine plasma powder as a function of preheating time at $25^{\circ} \mathrm{C}$ or $40^{\circ} \mathrm{C}$.

(A) SA' grade (SA grade containing the same amount of water as that of 2 nd grade); (B) 2nd grade; (C) 2nd grade

Salt-ground meats were prepared from walleye pollack frozen surimi with and without $0.5 \%$ bovine plasma powder. Moisture content of SA grade-frozen surimi was adjusted to the same level as that of 2 nd grade surimi by adding water. Preparation of two-step heating gels was then made as in Fig. 1, except that the preheating of the salt-ground meat was made at $25^{\circ} \mathrm{C}$ or $40^{\circ} \mathrm{C}$. The breaking strength $(\mathrm{g})$ and the breaking strain $(\mathrm{mm})$ were measured also as in Fig. 1.

- without plasma; 0 , with $0.5 \%$ plasma.

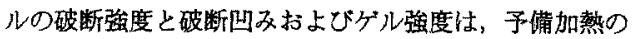
時間にともない，いすれる類似の增加傾向を示し，また 5 時間後むまだ增加途中にあるが，ブラズマ添加のもの のほうが常に高い值を示した。たたし，その增加の程度 は，2級品からのむのに比へて，SA'級品からのむのの ほうが相対的に少なく，この傾向は加水する前のSA 級 からの製品の場合とほとんど同じであった。

また，40ㄷで予備加熱して得たかまぼどルの揚合 む， SA' 級品からのほうが高いゲル物性を示すむのの， フラズマによるその強化效果恃見加け上小さく，最大檤 に招ける增加は破断強度で $4 \%$ ，破断凹及で $3 \%$ 上， 加水しないSA 級からの場合と同じであった。したがっ

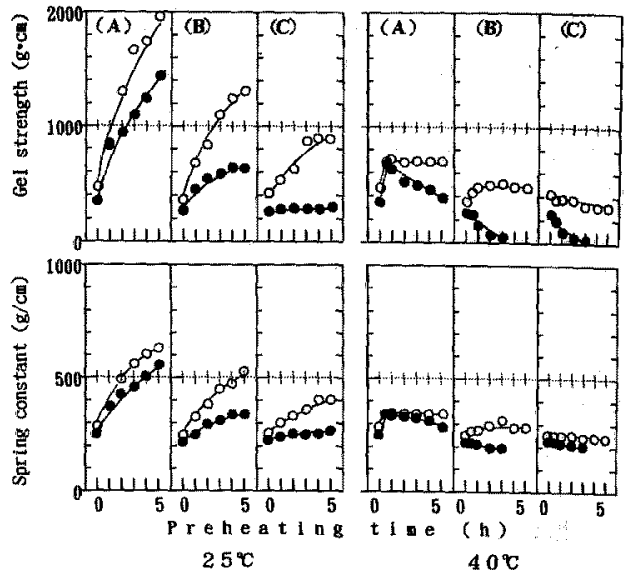

Fig. 6. Comparison of changes in gel strength and spring constant between two-step heating gels from SA' grade (SA grade adjusting moisture content) and 2nd grade frozen surimis with and without bovine plasma powder as a function of preheating time at $25^{\circ} \mathrm{C}$ or $40^{\circ} \mathrm{C}$.

From the data shown in Fig. 5, the gel strength and the spring constant were calculated the same as in the legend of Fig. 3.

(A) $\sim(\mathrm{C})$, - , and $O$; the same as in the legend of Fig. 5.

て，プラズマによるかまぼこのゲル物性に対する見かけ の強化度合は，すり身に対する加水の有無，すなわちか まほこ中の Mf タンパク質淟度の多少を反映した結果で はなかった。

\section{考察}

プラズマを添加したかまぼこを噒んだときの官能的な 評価仙すり身の等級によって硬さやしなや加さの程度 に羑異はあるすのの，無添加で調製したがぼこのゲル 物性を全体的により強くした食感であった。25ㄷで予 備加熱したがすぼこルに括いては，著しく硬いむのに なったが同時にしなやかさむ伴っており，市眅品と此べ て違和感をほとんど感しなかった。また，ゲル強度とバ 亦定数の関係加ら，破断強度と破断田及が比較的つりあ いの取れた状態で強化されたことかわかか。一方， $40^{\circ} \mathrm{C}$ で予備加熱したがほこのゲルでは，プラズマ無 添加の昜合はいわゆる戻りを伴った食感であるのに対 し，プラスマ添加により明ら加に異なり，いわゆる暦り を感じさせなかった。また，プラズマ添加のゲル旗度と バネ定数の值が予備加熱時間の経過に伴ってほほ一定と なっていることからほほほ同じの物性を保っていること がわかる。 
ブラズマによるかまほこのゲル物性の強化は，すり身 の等秝に拘わらず，同しよらな㑯向で現れることから， すり身からかまほこゲルを形成する機構に対して同じよ うに作用した結果であると推察出来る。たたし，その強 化の度合は，等級の务るすり身加らのむのにおいて相対 的に大きく現れるが，等級の優れたすり身からの製品の ゲル物性レベルには達しないので, プラズマによる強化 の機構はすり身中の Mf タンパク質のゲル形成機構とは 本質的に翼なっている上考えられる。それゆえ，40ㄷ で予備加熱したかまほこゲルの場合のように，㒖か 0.5\%のフララズマの添加がゲル構造を補強し，予備加熱 に伴う著しいゲル物性の劣化を抑制するむのと考えられ る。

また，等級の異なるすり身から製造するかまほこのゲ 儿物性に対するブラズマによる強化度合の差異は，すり 身中の Mf タンパク貿浱度の高低を反映した結果ではな いことから，すり身中の Mf タンパク質の質的な相違2) を唯る程度反映している可能性が考えられる。

なお，予備加熱における塩ずり肉中のミオシン重鎖の 多量化反机に対するブラズマの影響を梌討した結果によ ると，既に報告したように，*5無添加の埸合に此べて， 見加け上ミオシン重鎖の減少を扣制しているにも拘ら ず，より分子サイズの大きな多量体の形成了を促進して いる。したがって，ブラズマ添加によるかまほこのゲル 物性の增加は，通常塩ずり肉中で起こるミオシン重鎖の

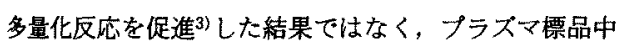

のなんらがタンパク成分がミオシン重鎖の多量体形成 反纫に参加し，複合体を形成することによると推定され た。これはすり身の等級に関係なく同槏に認められたこ とであり，詊細は別に埌ずる。

また，上記の影響がブラズマ標品中に含事れている多 種にわたるタンパク質成分中到のどの成分に依存してい るかは未だ不明であるが、フィブリノーゲンなとの特定 成分 ${ }^{5,6)}$ に注目して現在追求している。

\section{謝辞}

本研究を進めるにあたり，ご悲篤なご指導とご校闃を いただいた元・北海道大学 教授 新井健一博士に心か ら感謝申し上げます。

\section{文 献}

1）阿部洋一：牛血獎粉末を添加したスケトウダラがほほの 品筫. 日水誌，60,779-785 (1994).

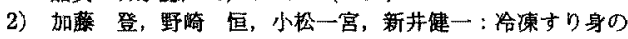

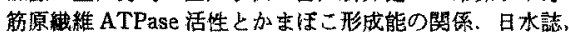
45, 1027-1032 (1979).

3）沼合忠弘：スケトウダラ塩ずり肉のダル形成（坐り）にお ける筋原線䊒タンパク質の変化に関する研究。学位論文， 北海道大学, 北海道, 1990 , pp. 76-80.

4) 生化学碚典，第 2 版，東京化学同人，東京，1991，p. 430.

5) E. A. Foegeding, W. R. Dayton, and C. E. Allen: Interaction of myosin-albumin and nyosin-fibrinogen to form protein gels. J. Food Sci, 51, 109-112 (1986).

6）六車三治男，速水紀文，杉本浩二，中村豊郎，沼田正寛， 吉原忠志：血被ブラズマ分画成分とミオシンBの相互作 用. 日食工誌, 37, 594-601 (1990)。

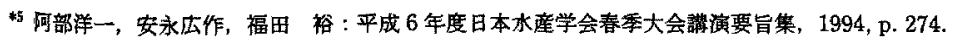

